
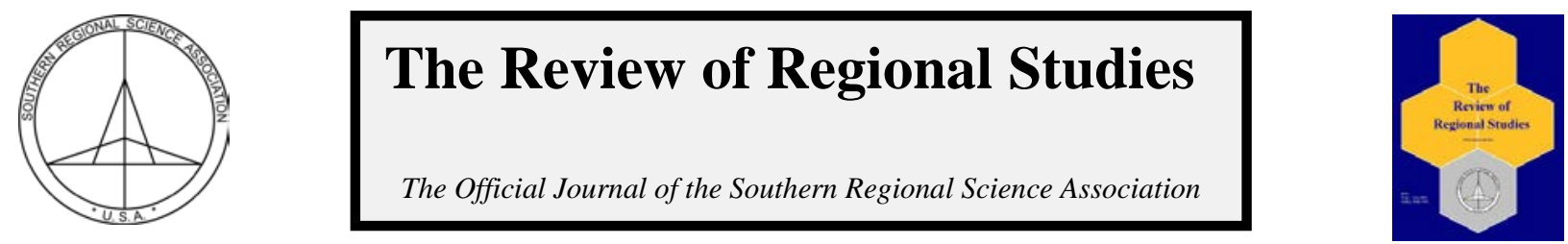

\title{
Market Differentiation and the Adoption of Economic Development Strategies: Explaining Policy Adoption in Metropolitan Areas
}

\author{
Michael R. Overton \\ Department of Politics and Philosophy, University of Idaho, USA
}

\begin{abstract}
Local government competition for private business investment is a central concern in polycentric governance. Previous research argues that competition for business investment is intense and ubiquitous across local governments (Peterson, 1981; Rubin, 1988). However, local government managers adopt policy and economic development strategies in the context of the strategies adopted by neighboring local governments. Do cities, knowing the economic development strategies of their neighboring cities, pursue similar types of businesses? Or do they strategically target different types of businesses to avoid the negative consequences of competition? Hypotheses are tested by applying product differentiation theory to policy adoption in metropolitan areas using spatial regression analysis on a sample of 2,299 cities. Results indicate that cities pursue similar development strategies as neighboring cities, but will implement increasingly differentiated strategies as population heterogeneity and political and bureaucratic incentives increase. Furthermore, this study finds that a city's reliance on the sales tax and the costs of competing for business location impact the type of development strategy used by a city.
\end{abstract}

Keywords: local government competition, policy adoption, agglomeration economies

JEL Codes: H77, R51

\section{INTRODUCTION}

Cities operate in a polycentric system of governments where the consequences of their decisions are not fully internalized (Ostrom, Tiebout, and Warren, 1961). The choices made by one local government ripple out to affect neighboring governments, the regional economy, and even overlapping state and federal governments. This fact is not lost on local government managers. While referencing the decisions made by neighboring jurisdictions, local government managers make strategic decisions to maximize the long-term benefits that accrue to their jurisdictions (Agranoff and McGuire, 2001; Frant, 1996). The resulting metropolitan ecology is characterized by collaboration, conflict, and competition.

The purpose of this study is to gain a greater understanding of the American metropolitan ecology by examining how interjurisdictional competition over industrial agglomerations impacts a city's choice of economic development strategies for attracting business. While previous research explores why local governments pursue economic development initiatives (Geotz and Kayser, 1993; Johnson and Neiman, 2004; Minkoff, 2012; Peterson, 1981; Pagano and Bowman, 1995) and why they adopt various types of economic development incentives (Hawkins and Andrew, 2010; Rubin and Rubin, 1987; Stokan, 2013; Warner and Zheng, 2013; Zheng and Warner, 2010),

Author and Writer is an Assistant Professor of Public Administration at the University of Idaho, 875 Perimeter Drive, Moscow, ID 83843. Corresponding Author: Michael Overton. Author E-mail: Moverton@uidaho.edu

(c) Southern Regional Science Association 2018.

ISSN 1553-0892, 0048-749X (online)

www.srsa.org/rrs 
these studies have left unaddressed why local governments strategically pursue distinct types of industrial agglomerations.

Previous research has argued that competition for business investment is intense and ubiquitous across local governments (Peterson, 1981; Rubin, 1988), resulting in the implicit assumption that as the provision of economic development incentives increases, competition for business investment increases. While reasonable, this assumption fails to acknowledge that neighboring local governments may pursue different industrial agglomerations from one another, and do so rationally. When a local government strategically targets businesses in an industry that neighboring jurisdictions are not pursuing, the negative consequences of competition, such as a "race-to-the-bottom" (Oates and Schwab, 1988), are dampened.

Do cities, knowing the economic development strategies (i.e., the industrial agglomerations being targeted) of their neighboring cities, pursue similar industrial agglomerations? Or do they strategically target different industries to avoid the negative consequences of competition? Although neighboring cities may aggressively pursue business investment, if each city pursues a different industrial agglomeration, then direct competition is low. The purpose of this study is to better understand when and why cities compete over similar industrial agglomerations.

Overall, the analysis supports four broad findings. First, cities pursue the same types of businesses as neighboring cities. Second, cities that pursue a differentiated manufacturing business base are more likely to do so when they have a heterogeneous population within the city and between their city and the regional metropolitan statistical area (MSA). This result is likely because heterogeneous populations increase the likelihood of institutional entrepreneurship. Third, a city's revenue or tax structure influences the magnitude and type of differentiated strategy a city pursues. Cities with heavy reliance on the sales tax are more likely to pursue retail industries, but less likely to pursue manufacturing industries. Fourth, as the costs of competing over the location of specific industries increase, cities are more likely to pursue different industries as part of a differentiated economic development strategy.

Policy makers and local government officials are being increasingly pressured to do more with fewer resources. By better understanding interjurisdictional competition over industrial agglomerations, policy makers can better formulate their local government's economic and community development strategy. This article provides insight into the formulation and implications of entrepreneurial cities in local government economic development.

\section{RELATED LITERATURE}

\subsection{Interjurisdictional Competition}

Interjurisdictional competition occurs in a local market for public goods, which is analogous to a private market where cities in a polycentric system of government compete to attract households and businesses. Local governments act like producers in a private market but provide local public goods, which are public goods with geographically bounded benefits (Bland and Overton, 2014; Hindriks and Myles, 2006). Households and businesses "shop" for public goods by exiting communities that do not match their preferences for public goods and entering communities that do match their preferences (Tiebout, 1956). Under certain conditions, interjurisdictional competition over a mobile tax base allows citizens and businesses to reveal their preferences for public goods by exiting communities whose bundle of goods they do not prefer 
and entering communities whose bundle of goods align with their unique preferences (Teske, Schneider, Mintrom, and Best, 1993).

There is a strong tradition in metropolitan governance research that assumes city governments always prioritize economic development relative to other policy priorities, which subsequently intensifies interjurisdictional competition. Peterson (1981) argues that all cities wish to maximize their economic position using development expenditures. Local officials and administrators are motivated to improve their community's economic position because increases in economic prosperity lead to a larger tax base (Peterson, 1981), are politically popular (Buss, 2001; Clingermayer and Feiock, 2001; Peterson, 1981), and increase the economic well-being of a city's residents (Peterson, 1981).

In seeking to maximize a city's economic position, cities compete with one another over business location. Cities use a variety of incentives such as direct subsides, tax incentives, lower tax rates, infrastructure development, and marketing to entice business investment into their jurisdictional boundaries. ${ }^{1}$ In Peterson's (1981) conception of interjurisdictional competition, all potential gains in economic prosperity through business location come at the expense of other cities - a zero-sum game (Porter, 2000). Increases in the tax base from business location are completely internalized by the city while neighboring jurisdictions receive no benefits from positive spillovers.

City governments are forced to compete with one another to attract businesses and improve their economic position. The resulting interjurisdictional competition is argued to be so intense that municipalities continually undercut competing municipality's business incentives to the economic detriment of both cities in a "race to the bottom" (Oates and Schwab, 1988). While the conformity of the "race to the bottom" model to reality is questionable (Fischel, 2001), it does emphasize the underlying assumption in metropolitan governance scholarship. Specifically, the assumption that cities share a strong and homogenous motivation to pursue economic development resulting in ubiquitous competition among local governments.

\subsection{Product Differentiation}

Based on Peterson's (1981) logic, it is easy to conclude that local governments are always in competition over business investment. However, this conclusion fails to acknowledge the varying ways in which local governments "compete." Product differentiation theory, which explains how and when private firms compete for a share of a market, can be used to explain how local governments compete for new business investment to add to their tax base.

Product differentiation is a production strategy used by private firms to maximize profits. Firms produce products that have varying degrees of similarity and dissimilarity to the products of their competitors. The degree to which differentiated products act as perfect substitutes determines the amount of differentiation (Beath and Katsoulacos, 1991). The closer the products are to becoming perfect substitutes, the more undifferentiated the products. Intense price competition is a hallmark of highly undifferentiated products, because similarities in characteristics and quality allow an informed consumer to easily substitute one undifferentiated good for another. In an undifferentiated product market, customers make their purchase based on the lowest price.

\footnotetext{
${ }^{1}$ Evidence suggests businesses are sensitive to both a city's tax rate and the tax incentives it offers (Hanson and Rohlin, 2011; Bland and Overton, 2014), especially when making their final location decisions (Bartik, 1991; Fisher and Peters, 1998).
} 
However, differentiated products are not perfect substitutes for each other. Highly differentiated product markets result in imperfect price competition because firms are no longer competing with other firms over a single consumer preference. Therefore, firms in an undifferentiated product market take on monopolistic tendencies. The more differentiated a product, the less sensitive a firm is to price changes in competing firms and, conversely, the less impact one's own firm has on competing firms. By differentiating their product, a firm lowers the amount of price competition for their product and, thus, has greater control over pricing decisions.

While some authors have accounted for product differentiation in a local market for public goods (Craw, 2008; Schnieder, 1989), their approach focused on the differentiation of public goods supplied. Local governments provide citizens bundles of goods that cannot be selectively unbundled and "purchased" individually. Because cities offer only bundles of goods, differentiation in a local market will be difficult to infer if we only examine what cities supply. To overcome this problem, this study explores how certain differentiated industrial agglomerations in a city are compared to neighboring cities. This approach accounts for differentiation in the demand for a city's bundle of goods rather than the supply. ${ }^{2}$

This study fills an important gap in our knowledge of local economic development by questioning the nature of interjurisdictional competition. Using product differentiation theory, this study examines the different rationales for pursuing an economic development strategy where neighboring cities pursue similar or different industrial agglomerations.

\section{CONCEPTUAL FRAMEWORK}

\subsection{Differentiation in Economic Development}

Residents of a local government are attentive to local economic development policy, which is crafted and implemented by city politicians and bureaucrats. The political salience of economic development in local politics (Buss, 2001; Peterson, 1981; Pagano and Bowman, 1995) greatly increases the perceived political costs of failed economic development policy compared to the benefits of successful innovative policy (Spindler and Forrester, 1993). Aware of the risks and rewards, politicians and bureaucrats prefer economic development policy that minimizes the chance of political fallout compared to policy maximizing the potential for economic growth (Mayhew, 1974; Spindler and Forrester, 1993).

An economic development strategy that focuses on attracting industrial agglomerations that are similar to neighboring cities' industrial agglomerations, referred to as an undifferentiated development strategy (UDS), is a lower risk proposition than pursuing a differentiated development strategy (DDS), the pursuit of industrial agglomerations different from that of neighboring cities. A UDS reduces risk to local government officials in three ways. First, it minimizes political fallout should the initiative fail to produce the promised benefits. Since residents evaluate their city's performance by comparing it to the performance of neighboring cities (Besley and Case, 1992; Brueckner, 1998; 2003; Buettner, 2001; Heyndels and Vuchelen, 1998; Ladd, 1992; Shleifer, 1985). A city that pursues industrial agglomerations substantially

\footnotetext{
${ }^{2}$ A potential criticism of this research method for exploring differentiation is that businesses and households make location decisions for a variety of reasons not associated with the bundle of goods being offered. While scholarship supports this assertion, most of the determinants are heavily influenced by the city or are mistakenly assumed to bind a household or business to that city. For example, retail firms often choose their location to take advantage of excellent foot-traffic. But, that desirable level of foot traffic is generally the result of purposeful planning and development by city officials.
}

(C) Southern Regional Science Association 2018. 
different from that of its neighbors' industrial agglomerations carries the risk of not only outright failure of its efforts but of underperformance relative to that of neighboring cities. Second, a UDS decreases design and implementation costs of the economic development strategy. Third, it increases perceived chances of success. Economic development initiatives are formulated in a highly uncertain environment where the range of potential strategies and outcomes are unknown (Ostrom and Ostrom, 1971). By adopting an economic development strategy similar to a successful strategy adopted by a neighboring city, the perceived risk of failure is reduced. A UDS will be the preferred strategy of risk-averse local government officials because it limits negative citizen evaluations, minimizes design and creation costs, and maximizes the perceived probability of success.

\subsection{Differentiation}

While an UDS offers political advantages, it is also associated with increased economic costs. When local governments adopt an UDS, product differentiation theory predicts that price competition among these local governments will be high. That is, contiguous cities with similar industrial agglomerations will compete through incentives to attract or retain businesses (Hanson and Rohlin, 2011). This type of competition is costly to local governments because it results in more business incentives and lower tax revenues. Conversely, when a city pursues a DDS, the city is no longer paying a premium to entice businesses away from other cities because it is no longer in heavy price competition for business investment (Brennan and Buchanan; 1980). Despite the economic benefits, DDS strategies are politically risky endeavors that risk-averse city officials will ultimately avoid. What turns risk-averse politicians into risk-takers? How do cities overcome the barriers to adopting a DDS?

A city will adopt a DDS when (1) the political risk of differentiation is minimized, (2) the costs for the differentiated strategy are low, and (3) the perceived chances of success are high. These three conditions can be met when the city, as an institution, behaves like a political entrepreneur. Political entrepreneurs are bureaucrats, politicians, or citizens that find unfulfilled public preferences and capitalize on the latent demand for those preferences by mobilizing a previously unorganized political coalition of supporting citizens (Schneider and Teske, 1992; Teske and Schneider, 1994). Institutional entrepreneurs are organizations (like city governments) that bear the political and coordination costs necessary to overcome institutional collective action problems in an institutional marketplace, such as a local market for public goods. Unlike political entrepreneurship, no single person needs to bear the entirety of the coordination costs and political risk. Activities of institutional entrepreneurs are executed by a variety of actors (or one very enterprising individual) within or associated with the city government. ${ }^{3}$ These actors are not individual political entrepreneurs, but when the actions of the many actors are aggregated to the level of an institution, the institution itself behaves entrepreneurially somewhat absolving city officials from bearing the political risk of pursuing a DDS strategy. The key differences between political and institutional entrepreneurs are the actors involved and the market that each entrepreneur is influencing. Political entrepreneurs are individuals influencing electoral markets, while institutional entrepreneurs are local governments, influenced by groups of individuals, behaving entrepreneurially in a group of competing institutions such as a local market for public goods.

\footnotetext{
${ }^{3}$ The differences between collective action problems and institutional collective action problems are beyond the scope of this manuscript. See Feiock (2013) for a detailed manuscript on institutional collective action.
}

(c) Southern Regional Science Association 2018. 
Institutional entrepreneurs play a key role in the establishment of a DDS. First, they bear the initial risk associated with adopting a DDS. Institutional entrepreneurs, like political entrepreneurs, organize political coalitions in support of a DDS. By organizing a previously unformed coalition in support of a DDS, politicians are given an opportunity to reap political benefits and avoid political fallout. Members of the influencing institutional entrepreneurial group are not immune to the consequences of political fallout, but it does provide individual politicians and decision makers protection because members of the new formed coalition can be blamed for any negative outcome resulting from the entrepreneurial behavior. Second, institutional entrepreneurs bear the costs of designing a DDS strategy. By initially articulating and eventually organizing a DDS strategy, institutional entrepreneurs decrease the political costs of formulating a new or original strategy. By allowing lower level bureaucrats, chambers of commerce, or outside consultants to identify an alternative economic development strategy, city officials shift the political risk and design costs associated with formulating a new economic development strategy onto other actors. Third, by identifying latent demand in a local market for public goods, institutional entrepreneurs overcome crucial information asymmetries. A DDS is more likely to succeed when cities in a public goods market are relatively homogenous, but the residents are relatively heterogeneous. Heterogeneous consumers have heterogeneous preferences that are not satisfied when the public goods market provides similar options. Institutional entrepreneurs are sensitive to the preferences of residents and the local market for public goods, which allows a city to act entrepreneurially while maximizing the chances of success.

Functionally, cities differentiate their development strategy in two distinct ways: (1) by pursuing an industrial agglomeration more intensely than their neighbors-a positive DDS, (2) by pursuing an industrial agglomeration less intensely than their neighbors-a negative DDS. The decision to pursue a positive or negative DDS is a straightforward decision dependent on the relative costs and benefits of pursing business from a specific industry.

\subsection{The Role of Benefits}

When pursuing businesses in a specific industrial agglomeration, a positive DDS is adopted when benefits accrue to city officials. City officials, either elected politicians or career bureaucrats, have distinct motivations. Bureaucrats seek to maximize revenue (Brennan and Buchanan, 1980; Lewis, 2001; Niskanen, 1975), while politicians maximize electoral benefits (Mayhew, 1974).

For motivated bureaucrats, a city's revenue structure will determine the relative benefits of business relocation and the merit of adopting a positive DDS for a particular industrial agglomeration. For example, a city's reliance on sales tax revenue increases the benefits of pursuing retail investment and decreases the marginal benefits of pursuing manufacturing investment. Politicians adopt a positive DDS to maximize electoral benefits. Specifically, politicians are concerned with increased employment (Clingermayer and Feiock, 2001). When unemployment is high, the relative benefits of a business relocating to a city are high because politicians gain electoral benefits by claiming credit for the job growth (Mayhew, 1974).

\subsection{The Role of Competition}

Cities adopting a negative DDS differentiate away from industrial agglomerations pursued by neighboring cities due to barriers to entry and competition costs. Barriers to entry or entry costs are monetary or non-monetary expenses that must be paid before a city can attract specific types of business investment or industrial agglomerations. For example, cities occasionally must invest upfront in infrastructure before they can attract a certain type of business. Manufacturing industries 
sometimes require specialized public utilities that prevent local governments from freely competing over this industry.

Competition costs are costs associated with incentives used to attract or retain business investment into a city. Competition costs for businesses will increase as more cities pursue the same types of businesses. Competition begets greater incentive use to attract a specific business base, which results in greater competition costs (Oates and Schwab, 1988). As a city's neighbors receive higher relative benefits from pursuing a certain industrial agglomeration, competition costs increase because that city is willing to pay more to attract businesses from that industry.

\section{DATA}

\subsection{Sample}

To test the why cities pursue UDS or DDS, a sample of cities located within MSAs ${ }^{4}$ is used as the unit of analysis. Only cities within MSAs are included because cities in an MSA are considered legally independent but economically interdependent. Cities in an MSA share a local market for public goods. Cities outside of an MSA are less economically interdependent to the extent that they are not part of a local market for public goods. The data are collected from three sources: the 2007 Census of Government Finance, the 2007 Economic Census, and the 2005-2009 American Community Survey (ACS).

The MSAs from ten states are the subject of analysis. California, Delaware, Florida, Louisiana, Montana, North Carolina, Oklahoma, South Dakota, Tennessee, and Texas were chosen because they provide a wide range of population sizes, industrial bases, demographics, environmental endowments, and, most importantly, sales tax administration and collection procedures. Census of government data from 2007 for all cities in the MSAs in these ten states were used in this analysis. ${ }^{5}$ The resulting sample contains 2,299 cities from 115 MSAs.

The primary reason for this sample is to control for sales tax administration and collection procedures that limit or enhance bureaucratic incentives to pursue retail businesses because they shape the competitive environment (or lack thereof). Accurately accounting for competitive pressures is essential to measuring the incentives and disincentives for pursuing a positive or negatives DDS. The laws and procedures governing sales tax administration and collection vary across states. These "institutional rules" affect the behavior of local government bureaucrats within those institutions (North, 1990). Depending on the state, sales tax law may incentivize interjurisdictional competition over retail business location, even encouraging zero-sum economic development behavior. The selected states create a sample of cities with a relatively even split between cities in states that incentivize a competitive environment (California and Texas,) and states whose sales tax administration procedures dampen the competitive environment (Delaware, Florida, Louisiana, Montana, North Carolina, Oklahoma, South Dakota, and Tennessee).

Three institutional rules are largely responsible for determining the competitive environment. (1) Uniform adoption of a local sales tax across all cities. This rule creates ubiquitous demand for businesses that generate a sales tax. (2) A maximum or fixed sales tax rate. Cities that can alter their sales tax rates can increase sales tax revenue without increasing local commerce,

\footnotetext{
${ }^{4}$ MSAs are defined as one or more contiguous counties containing a core urban area with a population of at least 50,000 people. The urban core is adjacent to territories that are strongly linked to the core urban area economically and socially. The strength of integration between an urban core and its surrounding jurisdictions is determined through commuting patterns (Blair, 1995).

${ }^{5}$ Cities not incorporated in the 2000 Census but listed in the 2007 Census of Governments were dropped from the sample.
} 
Table 1: Sample Breakdown

\begin{tabular}{lccccccccccc}
\hline \hline State & TX & CA & DE & MT & SD & LA & FL & NC & OK & TN & Total \\
MSA Cities & 699 & 432 & 35 & 13 & 50 & 121 & 324 & 273 & 192 & 160 & 2299 \\
\% of Sample & 30 & 19 & 2 & 1 & 2 & 5 & 14 & 12 & 8 & 7 & \\
\hline \hline
\end{tabular}

giving cities a way to circumvent competition and still increase local revenue. However, cities without this option can only increase sales tax revenue by increasing commerce resulting in greater city incentives to pursue retail firms. (3) Sales tax allocation based on point of sale rather than population. Point of sale rules allow a city to collect the sales tax on transactions that incur in their city, effectively internalizing all sales tax revenue benefits associated with retail business location. By internalizing the benefits of retail sales location, a zero-sum game is effectively created where only one city benefits.

California and Texas possess all three provisions resulting in highly competitive environments. Delaware and Montana, however, do not allow their local governments to collect a sales tax. Florida and North Carolina allow cities to collect revenue from sales tax, but city sales tax revenue is not allocated solely on point of sale transactions. Counties levy a sales tax, but then revenue is allocated among cities in the county based on their pro rata share of the population or taxable property values, with the residual amount of revenue going to the county. Oklahoma and Louisiana represent states where the sales tax laws are like those in California and Texas with one exception, cities in Oklahoma and Louisiana set their own sales tax rate. South Dakota and Tennessee are not highly competitive states for reasons different than the rest of the sample. South Dakota has the broadest sales tax base in this sample and includes services in addition to transactions on goods (Tax Foundation Staff, 2011). A sales tax base this broad means that a wide range of industries, in addition to retail businesses, will enable South Dakota cities to increase their sales tax base. Interjurisdictional competition in Tennessee is limited because the sales tax levied by counties overrides any sales tax levied by cities in the county, which decreases a city's desire to maximize that revenue source. A breakdown of the sample can be seen on Table 1.

\subsection{Dependent Variable}

The dependent variable is business agglomeration, the geographic agglomeration of businesses from the same industry. This concept is operationalized as the location quotient (LQ) of retail employment and of manufacturing employment in each city. A LQ is an index that measures the agglomeration of an industry in a city relative to the regional concentration of that industry. Specifically, a LQ uses industry employment data to calculate the ratio of the share of the city's employment comprised of a specific industry compared to the MSA's share of an industry's employment relative to total MSA employment.

The LQ of industry $i$ in geographic area $j$ is calculated using Equation (1) below:

$$
L Q_{i j}=\frac{\left(X_{i j} / X_{* j}\right)}{\left(X_{i *} / X_{* *}\right)}
$$

where $X_{i j}$ is the total number of full time employees in industry $i$ in city $j ; X_{* j}$ is the total number of full time employees in all industries * in city $j ; X_{i *}$ is the total number of full time employees in industry $i$ in MSA *; and $X_{* *}$ is the total number of full time employees in all industries * in MSA *. When a city's LQ is greater than one, then industry $i$ is considered geographically clustered in that city compared to other cities in the MSA. 
The LQ measure requires employment data, which was collected from the 2007 Economic Census. ${ }^{6}$ Sectorial employment is determined using the North American Industry Classification System (NAICS), which groups businesses with similar products or services into the same category. The classification is divided into NAICS codes with various levels of classification detail. Retail and manufacturing agglomeration are selected because each industry provides distinctly different benefits to city officials. Retail businesses are attractive when the goal of an economic development policy is to increase sales tax revenue-a bureaucratic rationale for business development. Manufacturing businesses are beneficial when the goal is to increase employment - a political rationale for business investment.

Bureaucrats are motivated by low-powered incentives and politicians are motivated by high-powered incentives (Frant, 1996). In the context of economic development, there are many benefits to pursuing business investment. However, the primary benefits are (1) increased city revenues and (2) increased employment. While both are beneficial to a city, they are each particularly beneficial to a subset of decision makers. Bureaucrats, incentivized to maximize city revenue, are more likely to pursue businesses that can increase tax revenue, and retail businesses increase sales tax revenue.

Politicians are motivated by electoral incentives, and increased employment from business investment allows them to claim credit for increases in job opportunities for residents (Mayhew, 1974). Most retail businesses employ a small number of employees, minimizing the political benefits from that type of business development. Manufacturing firms offer larger amounts of long-term employment opportunities. Politicians play a key role in attracting these firms (Clingermayer and Feiock, 2001) and gain the most electorally from the location of a manufacturing firm. However, manufacturing firms offer little in the way of direct increases to city revenue and, thus, are primarily attractive to politicians and not bureaucrats. ${ }^{7}$

To test both the decision to adopt (1) an UDS versus a DDS and (2) a positive or negative DDS, two permutations of the dependent variable are needed. To test the UDS/DDS decision, Equation (2) is used:

$$
\text { Degree of Differentiation }[D D] L Q_{i j}=\left|1-L Q_{i j}\right| \text {. }
$$

Since MSA average LQ is 1 , the absolute value of 1 minus LQ approximates how differentiated a city is compared to the regional average. As a city's $D D L Q_{i j}$ approaches zero, that city can be characterized as adopting more and more of an UDS strategy, yet as the value increases the city is taking on more of a DDS strategy. To test the determinants for adopting a negative or positive DDS, the standard LQ is used.

\subsection{Independent Variables}

\subsubsection{Institutional Entrepreneurs}

This study proceeds, not by operationalizing institutional entrepreneurs directly, but by accounting for the local demographic conditions that make the emergence of an institutional entrepreneur more likely. The local demographic conditions that increase the chances of an

\footnotetext{
${ }^{6}$ Employment data are only provided for cities with a population of 2,500 or greater, and the statistical technique used to analyze the data requires complete data on all cities for a geographical area.

7 This argument is not suggesting that politicians only pursue manufacturing firms and bureaucrats only pursue retail firms. It is only positing that manufacturing firms are more sensitive to the electoral calculations of politicians and that retail firms are more sensitive to the revenue maximizing calculations of bureaucrats.
}

(C) Southern Regional Science Association 2018. 
institutional entrepreneur emerging are the homogeneity of a city's population, population growth, and city-MSA racial homogeneity. Heterogeneous populations provide greater opportunities for political entrepreneurs (Schneider and Teske, 1992). These divergent populations can be mobilized, which provides the political base of an institutional entrepreneur. This variable is called racial homogeneity and is operationalized as the percent of a city's population that is non-white.

In addition, the population change between 2000 and 2007 is included because pro-growth and anti-growth politics play an important role in the emergence of a political entrepreneur. Growing communities make mobilizing citizens more likely due to the strain on city services caused by the population growth (Schneider and Teske, 1992). Overall, a growing and/or a heterogeneous population provides institutional entrepreneurs opportunities to lessen the political costs of adopting a DDS, by mobilizing a supporting group of citizens.

The city-MSA racial homogeneity variable is the difference between the standard deviation of a city's percent non-white population and the percent non-white population of the MSA. This measure captures the deviation of a city's population away from the regional population. A city with a population highly deviated from the regional population demographics is more likely to adopt a DDS. A city with a deviated population is less likely to have identical preferences to their neighbors, and, thus, the costs of deviating from an UDS economic development strategy will be lower.

\subsubsection{Benefits}

The relative benefits are operationalized as a city's reliance on sales tax and the unemployment rate. A city's reliance on sales tax is the percent of that city's own source revenue that is sales tax revenue. The unemployment rate used in this study is the percent of a city's population that is not employed between the ages of 20 and 64 .

\subsubsection{Entry and Competition Costs}

Entry and competition costs determine the relative benefits of pursuing a DDS. Entry costs are operationalized as the utility capital outlays in a city and competition costs are operationalized as the spatial $\operatorname{lag}^{8}$ of a city's sales tax reliance and the spatial lag of utility capital outlays in a city.

Utility capital outlays are direct expenditures on buildings, grounds, the purchase of land, equipment, and structures for government owned utilities (U.S. Census Bureau, 2013) and is used to capture the entry costs associated with the location of manufacturing firms. These firms require higher capacity utilities to meet the demand of high production and waste disposal.

As cities increasingly depend on sales tax revenue, they are more willing to pay the competition costs associated with businesses that increase their sales tax base. By spatially lagging a city's reliance on sales tax, we can determine the average sales tax reliance of neighboring cities, which gives an approximation of competition costs.

However, competition costs need to be operationalized differently when the dependent variable is manufacturing agglomeration because sales tax reliance will not intensify competition over manufacturing firms. Instead, the spatial lag of utility capital outlays (logged) is used to operationalize competition costs. As a city's neighbors pay for utility capital outlays, it means that they have paid the entry costs to compete for various manufacturing firms.

\footnotetext{
${ }^{8} \mathrm{~A}$ variable averaged across neighboring cities to the focal as defined by the spatial weights matrix

(c) Southern Regional Science Association 2018.
} 


\subsubsection{Development Effort}

Development efforts of a city are also likely to affect how actively a city pursues businesses. Total highway expenditures are fundamental to commerce and transportation and are a common indicator of development (Minkoff, 2012; Peterson, 1981). Total highway expenditures are the sum of funds spent on capital outlay, current operations, interest on debt, assistance and subsidies, and insurance benefits and repayments.

Direct expenditures on parks and recreation capture a city's attempt to differentiate itself from competing cities because a city's parks help to create a distinctive identity for a city through public art, park design, and the provision of various activities (Minkoff, 2012). The greater the total parks expenditures, the greater the attempts to pursue a differentiated resident base.

\subsubsection{Fiscal Policy Space}

Fiscal policy space refers to the exogenous parameters that affect the range of policy decisions city officials can make (Hendrick and Crawford, 2014). This concept is measured by the city's population (logged), city area in square acres (logged), the percent of total revenue that comes from intergovernmental revenue, and the household median income (logged). These measures capture many of the exogenous constraints on the decision to adopt a UDS or DDS. Population size determines the relative number of people affected by developmental decisions. City area determines cost of services and land available for commerce. Percent of intergovernmental revenue captures a city's dependence on outside funding. Finally, household median income captures the wealth and spending capacity of a city’s residents.

\subsubsection{Agglomeration Forces}

To account for economic agglomeration forces, percent of the population with a bachelor's degree or higher and commute time will be included. Education allows the model to take into account the importance of labor market pooling, while commute time allows the model to account for travel costs.

\subsubsection{Competition}

Given the role of competition, it is important to consider variables that either increase or decrease the competitive pressures placed on a city. Three variables are used to account for complications to competition: the number of cities in an MSA, whether the city is a principal city in the MSA, and the competitive environment.

Principal cities are cities at the core of an MSA with the largest population (over 10,000 population), with a population between 50,000 and 250,000 and more workers commuting into the city than residents, or a city with a population between 10,000 and 50,000 where at least 1/3 the population of the largest city and the number of commuting workers exceeds the population. Principal cities often have a high service demand and a weakened tax base because of the large number of commuters. MSA size is the number of cities in an MSA. It captures the number of potential interjurisdictional competitors. As the number of cities increases, the number of competitors increases. More competitors give cities more opportunities for adopting a DDS through industrial specialization. Competitive environment is operationalized as a dummy variable coded as 1 if the city is in either Texas or California and 0 otherwise. As discussed in the sample selection section, sales tax rules can increase or dampen interjurisdictional competition over retail businesses. A summary of the descriptions and data sources for all variables can be found on Table 2.

(c) Southern Regional Science Association 2018. 
Table 2: Data Sources and Variable Descriptions

\begin{tabular}{|c|c|c|}
\hline Dependent Variables & Data Source & Descriptions \\
\hline Retail DD LQ & EC & Absolute value of 1 minus retail LQ \\
\hline Manufacturing DD LQ & EC & Absolute value of 1 minus manufacturing LQ \\
\hline Retail Agglomeration & EC & $\begin{array}{l}\% \text { of a city's total employment from retail businesses divided } \\
\text { by \% of a MSA's total employment from retail businesses }\end{array}$ \\
\hline Manufacturing Agglomeration & EC & $\begin{array}{l}\% \text { of a city's total employment from manufacturing } \\
\text { businesses divided by \% of a MSA's total employment from } \\
\text { manufacturing businesses }\end{array}$ \\
\hline Independent Variables & Data Source & Descriptions \\
\hline \multicolumn{3}{|l|}{ Institutional Entrepreneur Variables } \\
\hline Racial Homogeneity (\%) & ACS & $\%$ of total population that is not-white/Caucasian \\
\hline Population Change (\%) & CEN \& COG & 2007 population divided by 2000 population \\
\hline City-MSA Racial Homogeneity & ACS & $\begin{array}{l}\text { Distance standard deviation of the city \% non-white } \\
\text { population minus MSA \% non-white population }\end{array}$ \\
\hline \multicolumn{3}{|l|}{ Relative Benefits/Costs Variables } \\
\hline Unemployment Rate (\%) & ACS & $\%$ of city's population that is unemployed \\
\hline Sales Tax Reliance (\%) & COG & $\%$ of a city's total own source revenue that is sales tax \\
\hline Utility Capital Outlays (log) & COG & The log of the expenditures on capital outlays \\
\hline \multicolumn{3}{|l|}{ Development Effort Variables } \\
\hline Total Highway Expenditures (log) & COG & The log of direct highway expenditures \\
\hline Total Parks Expenditures (log) & COG & The log of direct parks and recreation expenditures \\
\hline \multicolumn{3}{|l|}{ Fiscal Policy Space Variables } \\
\hline Intergovernmental Revenue (\%) & COG & $\%$ of total revenue from state and federal grants \\
\hline City Area (log) & COG & The log of a city's sq. mileage \\
\hline Population (log) & COG & The log of a city's population \\
\hline Median Income (log) & ACS & The log of a city's median household income \\
\hline \multicolumn{3}{|l|}{ Agglomeration Force Variables } \\
\hline Education (\%) & ACS & $\%$ of population with a Bachelor Degree or higher \\
\hline Commute Time (log) & ACS & The log of the mean commute time to work \\
\hline \multicolumn{3}{|l|}{ Competition Variables } \\
\hline MSA Size & TIGER & \# of cities in an MSA \\
\hline Principal City & ACS & $\begin{array}{l}\text { Dummy variable- } 1 \text { if city is a principal city in their respective } \\
\text { MSA, } 0 \text { otherwise }\end{array}$ \\
\hline Competitive Environment & TIGER & $\begin{array}{l}\text { Dummy variable- } 1 \text { if city is in Texas or California, } 0 \\
\text { otherwise }\end{array}$ \\
\hline
\end{tabular}

Notes: CEN-2000 Census; EC-2007 Economic Census; COG-2007 Census of Government-Finance; ACS-2005-2009 American Community Survey; TIGER-2007 Census Tiger Shapefiles

\subsection{Missing Data}

Anytime a spatial pattern is present, complete data are needed or else the threat of bias increases with every missing observation. Imputation methods allow for the inclusion of spatially lagged data in otherwise incomplete observations (LeSage and Pace, 2004). While the imputed observations are of limited inferential value, imputation does allow for non-imputed values in an observation with missing data to be spatially lagged. Missing data is imputed using an iterative 
process that utilizes random forests called MissForest (Stekoven and Buhlmann, 2012). MissForest makes no parametric assumptions, can account for unspecified interactions and non-linear relationships, and outperforms other methods regardless of the number of missing values or the number of variables in a dataset (Richards, et al, 2012; Stekoven and Buhlmann, 2012).

In the dataset, there are a total of 86 missing observations across all independent variables, which constitutes 0.12 percent of the observed independent variables. Because the dependent variables come from the economic census, a considerable amount of the observations are missing because the economic census only provides data for cities with a population of 2,500. There are 1,712 missing values for manufacturing agglomeration and 1,208 for retail agglomeration. ${ }^{9}$ The Out of Bag (OOB) error estimates provide a good measure of imputation accuracy (Stekhoven and Buhlmann, 2012) where values close to 0 indicate good performance and values close to 1 indicate bad performance (Stekhoven, 2011). The OOB for the IV imputation was .0020 and the OOB for the DV's (estimated at the same time) was 7.08e-08, indicating excellent performance.

\subsection{Methodology}

Central to this article is a theory that articulates spatial dependence-a city's economic development decisions are strategically made given the strategies of neighboring cities. In spatial analysis, the attributes of a city are analyzed in conjunction with the attributes of its neighbors. Spatial estimation techniques allow researchers to see how the attributes of a city's neighbors affect the city itself. In the context of spatial analysis, "focal city" is used throughout this article, which refers to all non-spatially lagged outputs from a spatial regression. To test spatial dependence, a spatial weights matrix (SWM) is employed that spatially relates cities to other cities in the sample. The SWM employed is a distance-based inverse weights matrix (ID-SWM). A city's neighbors are classified as all cities within $100 \mathrm{~km}$ of the focal city.

Though all cities within $100 \mathrm{~km}$ of the focal city are considered neighbors, not all neighbors are weighted equally. An ID-SWM weights neighbors $1 /$ (distance), which means that as distance from the focal city increases, a neighboring city is weighted less. Since proximity is often associated with a city's perceived level of economic development competition (Geotz and Kayser, 1993; Minkoff, 2012), an ID-SWM weighting scheme is appropriate.

A Global Moran's I test is run on retail agglomeration, and manufacturing agglomeration. The results indicate that there is statistically significant spatial autocorrelation present in both variables. ${ }^{10}$ Moran's I test statistics are not directly interpretable, instead they indicate that there is a positive spatial relationship in each variable. In addition, the significance of Moran's I test statistic indicates that spatial autocorrelation is present and thus assumptions of the Ordinary Least Squares (OLS) model are violated. Spatial Durbin Models (SDM) are employed to account for various specifications of spatial autocorrelation.

To test the central argument of this article, a statistical method is needed that allows for the values of neighboring jurisdictions to impact the central jurisdiction. To accomplish this, a SDM model is used. OLS estimation procedures require that errors are independent and that there are no omitted variables. However, these assumptions are violated when the value of the dependent variable is spatially correlated with its neighbors. The SDM accounts for spatially lagged

\footnotetext{
${ }^{9}$ In the census, sometimes precise numbers are not given but a range is provided to prevent divulging proprietary information.

${ }^{10}$ Statistical significance is determined using the permutation method. The permutation method uses Monte Carlo simulations (100 draws in this study) against a null hypothesis of randomization to test for spatial patterns in a variable.
}

(c) Southern Regional Science Association 2018. 
Table 3: Descriptive Statistics

\begin{tabular}{lcccccc}
\hline & Mean & SD & Median & Min & Max & Range \\
\cline { 2 - 6 } Manufacturing Agglomeration & 2.84 & 1.22 & 3.20 & 0.10 & 8.24 & 8.14 \\
Retail Agglomeration & 1.56 & 0.57 & 1.66 & 0.07 & 4.48 & 4.41 \\
Racial Homogeneity (\%) & 34 & 26 & 27 & 0 & 100 & 100 \\
Population Change (\%) & 23 & 66 & 7 & $(95)$ & 1,179 & 1,275 \\
City-MSA Racial Homogeneity & 18 & 14 & 16 & 0 & 73 & 73 \\
Unemployment Rate (\%) & 7 & 4 & 6 & 0 & 57 & 57 \\
Sales Tax Reliance (\%) & 13 & 15 & 10 & 0 & 100 & 100 \\
Utility Capital Outlays (log) & 3,073 & 30,404 & 0 & 0 & $1,045,707$ & $1,045,707$ \\
Total Highway Expenditures (log) & 4,313 & 18,663 & 378 & 0 & 587,440 & 587,440 \\
Total Parks Expenditures (log) & 3,654 & 15,212 & 131 & 0 & 386,290 & 386,290 \\
MSA Size & 58 & 58 & 34 & 1 & 203 & 202 \\
Intergovernmental Revenue (\%) & 13 & 16 & 8 & 0 & 100 & 100 \\
City Area (log) & $39,360,771$ & $112,230,031$ & $11,790,597$ & 42,051 & $2,265,279,3682,265,237,000$ \\
Population (log) & 29,024 & 119,850 & 4,238 & 8 & $3,849,378$ & $3,849,370$ \\
Median Income (log) & 53,992 & 27,586 & 46,936 & 6,250 & 250,000 & 243,750 \\
Principal City & 0.11 & 0.32 & 0 & 0 & 1.00 & 1.00 \\
Education (\%) & 24 & 17 & 19 & 0 & 100 & 100 \\
Commute Time (log) & 25 & 6 & 25 & 9 & 54 & 45 \\
\hline \hline
\end{tabular}

dependent variables allowing for efficient and unbiased estimation. In addition, the SDM allows for the estimation of spatially lagged independent variables. In short, the effects that neighboring jurisdictions have on business location in another jurisdiction can be tested with the SDM model.

The SDM model is stated in Equation (3) below:

$$
y=\boldsymbol{\beta}_{0}+\rho \boldsymbol{W} \boldsymbol{y}+\boldsymbol{X} \boldsymbol{\beta}+\boldsymbol{W} \boldsymbol{X}_{\mathbf{0}} \boldsymbol{\gamma}+\boldsymbol{\varepsilon}
$$

where $y$ is the dependent variable, $\boldsymbol{\beta}_{\mathbf{0}}$ is the intercept, $\rho$ is the coefficient of the spatially lagged dependent variable $(\boldsymbol{y})$ weighted by a spatial weights matrix $\boldsymbol{W}, \boldsymbol{\beta}$ is the coefficient for the vector of independent variables $\left(\boldsymbol{X}_{\mathbf{0}}\right), \boldsymbol{\gamma}$ is a vector of the spatially lagged independent variables $\left(\boldsymbol{X}_{\mathbf{0}}\right)$ weighted by a spatial weights matrix $\boldsymbol{W}$, and $\boldsymbol{\varepsilon}$ is the error term. A spatial weights matrix (i.e., IDSWM) relates each city to its neighboring cities. While all cities are treated as neighbors in a spatial weight matrix, the strength of the relationship between cities decreases with increasing distance from the focal city. The SDM allows for efficient and unbiased estimates of the impact that neighboring cities have on the focal city. The SDM models are estimated using maximum likelihood estimation procedures to avoid inflation of standard errors from the correlation between the dependent variable and its spatial lags (Pace and LeSage, 2009). Two models are estimated for each dependent variable: spatial lag models with state fixed effects and spatial lag models with a composite fixed effect (i.e., competitive environment).

\section{RESULTS}

Table 3 presents the descriptive statistics for the variables used in the analysis. Table 4 presents results from Models 1 and 2 that test UDS/DDS decisions using the DD LQ. Table 5 
Table 5: Retail Agglomeration

\begin{tabular}{|c|c|c|c|c|c|c|c|c|}
\hline \multirow{4}{*}{$\begin{array}{l}\text { Intercept } \\
\text { Racial Homogeneity (\%) }\end{array}$} & \multicolumn{4}{|c|}{ Model 3 - State FE } & \multicolumn{4}{|c|}{ Model 4 - Composite FE } \\
\hline & \multirow{2}{*}{-5.907} & \multicolumn{3}{|c|}{ Spatial Lag } & \multirow{3}{*}{$\begin{array}{c} \\
-5.924 \\
>0.000\end{array}$} & \multirow[b]{2}{*}{ * } & \multicolumn{2}{|c|}{ Spatial Lag } \\
\hline & & & & & & & & \\
\hline & $>0.000$ & & 0.007 & $* *$ & & & 0.006 & $* *$ \\
\hline Population Change (\%) & 0.023 & & -0.302 & $* *$ & 0.024 & * & -0.112 & \\
\hline City-MSA Racial Homogeneity & 0.001 & & 0.013 & $* *$ & 0.001 & & 0.006 & \\
\hline Unemployment Rate (\%) & 0.003 & $* *$ & -0.058 & $* *$ & 0.003 & * & -0.049 & $* *$ \\
\hline Sales Tax Reliance (\%) & 0.217 & $* * *$ & -0.773 & & 0.047 & & 0.995 & $* *$ \\
\hline Competitive Environment*Sales Tax & & & & & & & & \\
\hline Reliance & & & & & 0.319 & $* * *$ & -3.044 & $* *$ \\
\hline MSA Size & $>0.000$ & & & & $>0.000$ & & & \\
\hline Education (\%) & -0.006 & $* * *$ & 0.010 & & -0.006 & $* * *$ & 0.004 & \\
\hline Commute Time (log) & 0.421 & $* * *$ & 0.299 & & 0.415 & $* * *$ & 0.088 & \\
\hline Median Income (log) & -0.025 & & -0.050 & & -0.031 & & 0.238 & \\
\hline Principal City & -0.150 & $* * *$ & -0.460 & & -0.159 & $* * *$ & -0.482 & \\
\hline City Area (log) & -0.076 & $* * *$ & 0.650 & $* * *$ & -0.075 & $* * *$ & 0.445 & $* * *$ \\
\hline Population (log) & 0.017 & & -0.511 & $* * *$ & 0.017 & & -0.430 & $* * *$ \\
\hline Total Highway Expenditures (log) & -0.014 & $* * *$ & -0.084 & & -0.015 & $* * *$ & -0.068 & \\
\hline Total Parks Expenditures (log) & -0.018 & $* * *$ & 0.107 & * & -0.019 & $* * *$ & 0.118 & $* *$ \\
\hline Intergovernmental Revenue (\%) & -0.079 & & 0.388 & & -0.106 & $* *$ & 0.568 & \\
\hline Competitive Environment & & & & & 0.476 & $* *$ & & \\
\hline $\mathrm{TX}$ & -0.059 & & & & & & & \\
\hline LA & -0.165 & & & & & & & \\
\hline TN & -0.141 & & & & & & & \\
\hline CA & 0.058 & & & & & & & \\
\hline NC & -0.084 & & & & & & & \\
\hline OK & -0.069 & & & & & & & \\
\hline SD & 0.037 & & & & & & & \\
\hline FL & -0.251 & $* *$ & & & & & & \\
\hline $\mathrm{MT}$ & -0.013 & & & & & & & \\
\hline
\end{tabular}

\begin{tabular}{|c|c|c|c|c|}
\hline Rho (Spatially Lagged DV) & 0.566 & $* * *$ & 0.589 & $* * *$ \\
\hline AIC & 2461.2 & & 2455.7 & \\
\hline AIC for LM only & 2472.6 & & 2469.8 & \\
\hline LM: Residual Autocorrelation & 0.071 & & 2.202 & \\
\hline LR: Model Significance & 2317.4 & $* * *$ & 897.51 & $* * *$ \\
\hline $\mathrm{N}$ & 2299 & & 2299 & \\
\hline
\end{tabular}

Notes: * $<90$ percent, $* *<95$ percent, $* * *<99$ percent; AIC-Akaike information criterion; AIC for LM only- AIC statistic for a linear version of the model.; LM: Residual Autocorrelation-Lagrange Multiplier test for residual autocorrelation; LR: Model Significance-LR test comparing each model to a model with only an intercept

Models 1 and 2 test how population heterogeneity (i.e., institutional entrepreneurship) and political/bureaucratic incentives affect a city's decisions to pursue a retail or manufacturing UDS or DDS. The analysis supports the role of population heterogeneity and political/bureaucratic 
Table 6: Manufacturing Agglomeration

\begin{tabular}{|c|c|c|c|c|c|c|}
\hline \multirow{3}{*}{ Intercept } & \multicolumn{3}{|c|}{ Model 5 - State FE } & \multicolumn{3}{|c|}{ Model 6 - Composite FE } \\
\hline & \multicolumn{3}{|c|}{ Spatial Lag } & \multicolumn{3}{|r|}{ Spatial Lag } \\
\hline & 12.925 & $* *$ & & 13.603 & $* * *$ & \\
\hline Racial Homogeneity (\%) & 0.008 & $* * *-0.002$ & & 0.008 & $* * *$ & -0.008 \\
\hline Population Change (\%) & 0.061 & $* * \quad 0.100$ & & 0.062 & $* *$ & 0.153 \\
\hline City-MSA Racial Homogeneity & 0.007 & $* * *-0.002$ & & 0.006 & $* * *$ & -0.001 \\
\hline Unemployment Rate (\%) & $>0.000$ & 0.009 & & 0.001 & & -0.017 \\
\hline Sales Tax Reliance (\%) & -0.366 & $* * * 1.362$ & & -0.385 & $* * *$ & 1.016 \\
\hline Utility Capital Outlays (log) & -0.007 & -0.124 & $* *$ & -0.008 & & $-0.132 * * *$ \\
\hline MSA Size & $>0.000$ & & & $>0.000$ & & \\
\hline Education (\%) & -0.011 & $* * * 0.032$ & $* *$ & -0.011 & $* * *$ & $0.033 * * *$ \\
\hline Commute Time (log) & 0.159 & $* * \quad-0.798$ & & 0.163 & $* *$ & $-1.091 *$ \\
\hline Median Income (log) & 0.139 & ** $\quad-1.096$ & * & 0.139 & $* *$ & $-1.253 * *$ \\
\hline Principal City & -0.624 & $* * * 0.998$ & & -0.619 & $* * *$ & 0.665 \\
\hline City Area (log) & -0.032 & -0.069 & & -0.032 & $*$ & 0.080 \\
\hline Population (log) & -0.258 & $* * * 0.376$ & * & -0.261 & $* * *$ & 0.279 \\
\hline Total Highway Expenditures (log) & -0.028 & $* * * 0.075$ & & -0.027 & $* * *$ & 0.067 \\
\hline Total Parks Expenditures (log) & -0.054 & $* * *-0.049$ & & -0.053 & $* * *$ & 0.042 \\
\hline Intergovernmental Revenue (\%) & 0.072 & -2.536 & $* * \mid$ & 0.100 & & 0.219 \\
\hline Competitive Environment & & & & 0.174 & $* * *$ & \\
\hline $\mathrm{TX}$ & 0.160 & & & & & \\
\hline LA & 0.078 & & & & & \\
\hline $\mathrm{TN}$ & 0.531 & $* * *$ & & & & \\
\hline CA & 0.186 & & & & & \\
\hline $\mathrm{NC}$ & 0.215 & & & & & \\
\hline $\mathrm{OK}$ & 0.026 & & & & & \\
\hline $\mathrm{SD}$ & 0.351 & $*$ & & & & \\
\hline FL & 0.337 & $*$ & & & & \\
\hline MT & 0.337 & $*$ & & & & \\
\hline Rho (Spatially Lagged DV) & 0.894 & $* * *$ & & & 0.948 & $* * *$ \\
\hline AIC & 4702.4 & & & & 4713 & \\
\hline AIC for LM only & 4757.1 & & & & 4807.5 & \\
\hline LM: Residual Autocorrelation & 3.754 & $*$ & & & 8.977 & $* * *$ \\
\hline LR: Model Significance & 2317.4 & $* * *$ & & & 891.46 & $5 * * *$ \\
\hline $\mathrm{N}$ & 2299 & & & & 2299 & \\
\hline
\end{tabular}

Notes: $*<90$ percent, $* *<95$ percent, $* * *<99$ percent; AIC-Akaike information criterion; AIC for LM only- AIC statistic for a linear version of the model.; LM: Residual Autocorrelation-Lagrange Multiplier test for Residual Autocorrelation; LR: Model Significance-Likelihood ratio test comparing each model to an intercept-only model 
incentives in the UDS/DDS decisions. Increased city-MSA racial heterogeneity (retail and manufacturing) and racial heterogeneity (manufacturing) were associated with increased differentiation strategies. Political and bureaucratic incentives also have a strong role in determining adoption of UDS or DDS. Surprisingly, higher unemployment rates - which was posited as a political incentive - were associated with higher manufacturing and retail DDS. This suggests that political incentives are an important catalyst for pursuing differentiated, rather than undifferentiated, strategies. Sales tax reliance was associated with increased retail DDS, but decreased manufacturing DDS, which is consistent with the hypothesized behavioral motivations of bureaucrats.

\section{$5.2 \quad$ Positive vs. Negative DDS}

Models 3, 4, 5, and 6 are deeper models exploring how population heterogeneity, political/bureaucratic incentives, and competition and entry costs impact the decision of local government managers to pursue a positive or negative DDS. The analysis also strongly supports the role of institutional entrepreneurs in in pursuing a positive DDS in manufacturing. Population heterogeneity appears to have a robust impact on manufacturing agglomeration both in the decision to pursue a DDS over a UDS and to pursue a positive DDS strategy.

Population heterogeneity has a limited role in determining a positive or negative retail DDS. Racial homogeneity and city-MSA racial homogeneity are statistically insignificant across both models, while population change is only statistically significant in Model 4. Yet, spatial lag of racial heterogeneity is significant across Models 3 and 4. The positive relationship indicates cities surrounded by racially heterogeneous cities are more likely to pursue a positive DDS. One possible explanation is that the risks associated with pursuing a positive DDS decrease in regions with many different heterogeneous preferences.

All four models provide strong support for the role bureaucratic incentives play in the decision to pursue a positive or negative DDS. The findings indicate a city's reliance on sales tax strongly incentivizes local governments to pursue a positive DDS in retail. This relationship is exacerbated when competitive environment and sales tax reliance are interacted in Model 4. The interaction term suggests that a city's reliance on sales tax revenue is positively associated with retail agglomeration when that city is in a state with highly competitive sales tax rules. Conversely, in cities with a less competitive environment, a city's reliance on sales tax does not affect whether a city pursues a negative or positive DDS. A city's reliance on sales tax incentivizes a negative DDS away from manufacturing agglomeration.

Unemployment rates provide local politicians electoral benefits and were predicted to incentivize a positive manufacturing DDS. However, Models 3 and 4 suggest that a higher unemployment rate incentivizes positive retail DDS, but Models 5 and 6 indicated there is no relationship between unemployment and the decision to pursue positive or negative manufacturing DDS. These findings are not surprising and do not directly contradict the proposed theory. More so, they suggest that electoral benefits drive positive DDS action in retail, but not manufacturing. Given the strong relationship between unemployment and manufacturing DDS in Model 2, it is likely that unemployment incentivizes manufacturing DDS, but not positive DDS, all things considered. The analysis suggests that competition costs, but not entry costs, incentivize cities to pursue a negative DDS. While utility capital outlays (i.e., entry costs) in Models 5 and 6 are statistically insignificant, the spatial lag of utility capital outlays is statistically significant. When neighboring cities pay entry costs, the number of potential competitors for manufacturing 
Table 7: Predicted and Actual Variable Relationships

\begin{tabular}{|c|c|c|c|c|c|c|}
\hline \multirow[b]{2}{*}{ Variables } & \multicolumn{2}{|c|}{$\begin{array}{c}\text { Predicted } \\
\text { Relationship }\end{array}$} & \multicolumn{2}{|c|}{ Results: Retail } & \multicolumn{2}{|c|}{$\begin{array}{c}\text { Results: } \\
\text { Manufacturing }\end{array}$} \\
\hline & No Lag & Lag & No Lag & Lag & No Lag & Lag \\
\hline \multicolumn{7}{|l|}{ DD LQ - Models 1 and 2} \\
\hline \multicolumn{7}{|l|}{ Institutional Entrepreneur Variables } \\
\hline Racial Homogeneity (\%) & + & N/A & N/A & N/A & + & $\mathrm{N} / \mathrm{A}$ \\
\hline Population Change (\%) & + & N/A & N/A & N/A & N/A & N/A \\
\hline $\begin{array}{l}\text { City-MSA Racial } \\
\text { Homogeneity }\end{array}$ & + & N/A & + & N/A & + & - \\
\hline \multicolumn{7}{|l|}{ Relative Benefits/Costs Variables } \\
\hline Unemployment Rate (\%) & + & - & + & N/A & + & + \\
\hline Sales Tax Reliance (\%) & $+/-$ & - & + & - & - & $\mathrm{N} / \mathrm{A}$ \\
\hline $\begin{array}{l}\text { Utility Capital Outlays } \\
\text { (log) }\end{array}$ & - & - & N/A & N/A & - & - \\
\hline $\begin{array}{l}\text { Rho-Spatially Lagged } \\
\text { Dependent Variable }\end{array}$ & N/A & + & N/A & + & N/A & + \\
\hline
\end{tabular}

\section{DDS - Models 3, 4, 5, and 6}

Institutional Entrepreneur Variables

Racial Homogeneity (\%)

Population Change (\%)

City-MSA Racial

Homogeneity

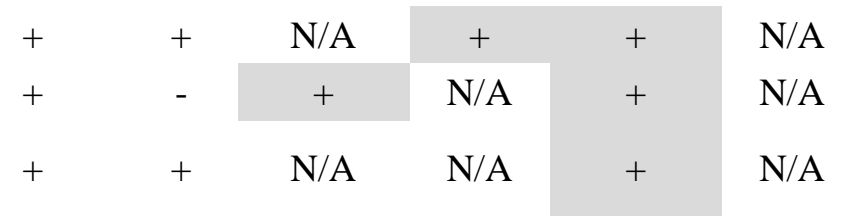

Relative Benefits/Costs Variables

Unemployment Rate (\%)

Sales Tax Reliance (\%)
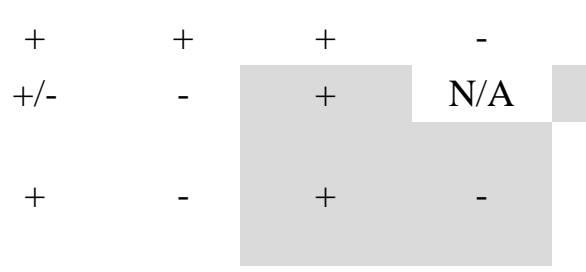

Reliance (\%)

Utility Capital Outlays

(log)

Interaction: Competitive

$+/$

$+/-$

N/A

$\mathrm{N} / \mathrm{A}$

Rho-Spatially Lagged

Dependent Variable

Note: Cells highlighted gray support theory.

investment increases resulting in a city pursuing a negative manufacturing DDS. The spatial lag of the interaction term, competitive environment and sales tax reliance, is associated with a negative DDS corroborating the disincentivizing behavior of competition costs.

\subsection{Rho}

The spatially lagged dependent variable, Rho, is positive and statistically significant in all six models, suggesting that cities are pursuing similar UDS/DDS strategies as their neighbors. LQs

(C) Southern Regional Science Association 2018. 
measure deviation from the regional agglomeration average. Rho's positive relationship and statistical significance indicate that neighboring cities deviate (or, conversely, do not deviate) from the regional agglomeration average in the same direction as neighboring cities. In other words, cities in close proximity exhibit parallel LQ patterns. This robust result is strong evidence that neighboring cities first and foremost pursue similar development strategies.

\section{CONCLUSION}

In general, the analysis corroborates the theory presented in this paper. Four conclusions can be drawn. First, evidence shows that cities adopt a UDS. A city's economic development strategy is influenced by the economic development strategies adopted by its neighbors and cities pursue the same businesses as their neighbors. This finding was robust across all six models at a high level of significance.

Second, population heterogeneity plays an important role in selecting a DDS over a UDS and in pursuing a positive manufacturing DDS. Manufacturing firms are not always desirable because with manufacturing comes negative externalities such as air or water pollution. Population heterogeneity increases the likelihood of an institutional entrepreneur emerging and institutional entrepreneurs are needed to mobilize a political coalition in support of manufacturing investment to overcome the political fallout associated with the negative externalities.

Third, negative and positive DDSs are influenced by revenue maximizing behavior. A city's revenue structure influences the type of business it pursues. Cities that rely on sales tax are more inclined to adopt a positive DDS in favor of retail investment and a negative DDS that avoids manufacturing investment. Unlike the relationship between business location and revenue structure, the analysis suggests a complex relationship between electoral benefits and business agglomeration. Specifically, politicians are looking to maximize their electoral benefits and do this through either credit claiming opportunities or symbolic action. Manufacturing investment is politically popular and provides electoral benefits even if no real employment growth occurs (Buss, 2001; Peterson, 1981). However, retail investment does not have the same symbolic strength as manufacturing investment because retail jobs are generally low paying and short term compared to manufacturing jobs. For retail investment to have the same electoral benefits as manufacturing investment, retail investment must fill an actual employment need in the city so that politicians can claim credit for job opportunities.

Fourth, competition costs incentivize adoption of a negative DDS. As neighboring cities rely more heavily on sales taxes, competition costs increase for retail agglomeration, making adoption of a UDS less beneficial. In addition, as more cities pay the entry costs associated with manufacturing investment, the competition for manufacturing investment decreases because adoption of a UDS provides fewer benefits and is costlier. Overall, competition costs appeared to play an important role in a city's decision to adopt a negative UDS.

When do cities' economic development efforts target similar types of business and when do they strategically target different types of businesses? Overall, the results suggest that city officials are primarily risk averse and want to limit potential fallout when adopting an economic development strategy. Political costs incentivize city officials to adopt an UDS and pursue the same businesses as their neighbors. Competition and entry costs end up pricing a local government out of certain industries, resulting in some cities adopting a negative DDS. However, benefits derived from a city's revenue structure influence a city toward adopting a positive DDS in certain 
circumstances. The benefits to a politician are difficult to measure and the direct benefits of increased employment were shown to be important only when the symbolic benefits were low.

In conclusion, competition between local governments is complex. City officials must balance a host of factors when making development decisions. Though this article focused on interjurisdictional competition over business investment, the lessons learned can be applied to a variety of policy areas. Adoption and implementation of sustainability policy, transportation policy, and even redistributive policy can be examined through the theory generated and tested above. This article is a starting point for a bigger conversation about policy adoption, interjurisdictional competition, and the spatial context of polycentric governance.

\section{REFERENCES}

Agranoff, Robert and Michael McGuire. (2001) “American Federalism and the Search for Models of Management.” Public Administration Review, 61(6), 671-681.

Bartik, Timothy. (1991) Who Benefits from State and Local Economic Development Policies? Upjohn Institute of Employment Research: Kalamazoo, Michigan.

Beath, John, and Yannis Katsoulacos. (1991) The Economic Theory of Product Differentiation. Cambridge University Press: Cambridge, U.K.

Besley, Timothy and Anne Case. (1992) "Incumbent Behavior: Vote Seeking, Tax Setting and Yardstick Competition.” American Economic Review, 85(1), 25-45.

Blair, John. (1995) Local Economic Development: Analysis and Practice. Thousand Oaks, CA: Sage Publications.

Bland, Robert L. and Michael Overton. (2014) “Assessing the Contributions of Collaborators in Public-Private Partnerships: Evidence from Tax Increment Financing.” American Review of Public Administration, 46(4), 418-435.

Brueckner, Jan K. (1998) "Testing for Strategic Interaction Among Local Governments: The Case of Growth Controls.” Journal of Urban Economics, 44(3), 438-467.

- (2003) "Strategic Interaction Among Governments: An Overview of Empirical Studies.” International Regional Science Review, 26(2), 175-188.

Brennan, G. and J. M. Buchanan. (1980) The Power to Tax: Analytic Foundations of a Fiscal Constitution. Cambridge University Press: Cambridge, U.K.

Buettner, Thiess. (2001) "Local Business Taxation and Competition for Capital: The Choice of the Tax Rate.” Regional Science and Urban Economics, 31(2), 215-245.

Buss, Terry F. (2001) “The Effect of State Tax Incentives on Economic Growth and Firm Location Decisions: An Overview of the Literature.” Economic Development Quarterly, 15(1), 90105.

Clingermayer, James C. and Richard C. Feiock. (2001) Institutional Constraints and Policy Choice: An Exploration of Local Governance. SUNY Press: New York, NY.

Craw, Michael. (2008) "Taming the Local Leviathan Institutional and Economic Constraints on Municipal Budgets.” Urban Affairs Review, 43(5), 663-690.

Feiock, Rick. (2013). “The Institutional Collective Action Framework.” Policy Studies Journal, 41(3), 397-425.

(c) Southern Regional Science Association 2018. 
Fischel, William A. (2001) The Homevoter Hypothsis: How Home Values Influence Local Government Taxation, School Finance, and Land-Use Policies. Harvard University Press: Cambridge, MA.

Fisher, Peter, and Alan Peters. (1998) Industrial Incentives: Competition among American States and Cities. Upjohn Institute of Employment Research: Kalamazoo, Michigan.

Frant, Howard. (1996) “High-Powered and Low-Powered Incentives in the Public Sector.” Journal of Public Administration Research and Theory, 6(3), 365-381.

Goetz, Edward G. and Terrence Kayser. (1993) "Competition and Cooperation in Economic Development: A Study of the Twin Cities Metropolitan Area." Economic Development Quarterly, 7(1), 63-78.

Hanson, Andrew and Shawn Rohlin. (2011) "Do Location-Based Tax Incentives Attract New Business Establishments?” Journal of Regional Science, 51(3), 427-449.

Hawkins, Christopher V. and Simon A. Andrew. (2010) "Linking Cooperative Arrangements and Economic Development Strategies: An Institutional Collection Action Framework.” International Review of Public Administration, 15(1), 1-16.

Hendrick, Rebecca and Jared Crawford. (2014) "Municipal Fiscal Policy Space and Fiscal Structure: Tools for Managing Spending Volatility.” Public Budgeting and Finance, 34(3), 24-50.

Heyndels, Bruno and Jef Vuchelen. (1998) “Tax Mimicking Among Belgian Municipalities.” National Tax Journal, 51(1), 89-101.

Hindriks, Jean and Gareth D. Myles. (2006) Intermediate Public Economics. MIT Press: Boston, MA.

Johnson, Martin and Max Neiman. (2004) "Courting Business: Competition for Economic Development Among Cities,” in Richard Feiock, ed., Metropolitan Governance: Conflict, Competition and Cooperation. Georgetown University Press: Washington, DC, 124-146.

Ladd, Helen F. (1992) “Mimicking of Local Tax Burdens Among Neighboring Counties.” Public Finance Review, 20(4), 450-467.

LeSage, James P. and R. Kelley Pace. (2004) "Models for Spatially Dependent Missing Data." The Journal of Real Estate Finance and Economics, 29(2), 233-254.

Lewis, Paul G. (2001) "Retail Politics: Local Sales Taxes and the Fiscalization of Land Use.” Economic Development Quarterly, 15(1), 21-35.

Mayhew, David R. (1974) Congress: The Electoral Connection, $2^{\text {nd }}$ ed. Yale University Press: New Haven, CT.

Minkoff, Scott L. (2012) “The Proximate Polity: Spatial Context and Political Risk in Local Developmental Goods Provision.” Urban Affairs Review, 48(3), 354-889.

Niskanen, William A. (1975) “Bureaucrats and Politicians.” Journal of Law and Economics, 18(3), 617-43.

North, Douglass C. (1990) Institutions, Institutional Change and Economic Performance. Cambridge University Press: Cambridge, U.K. 
Oates, Wallace E. and Robert M. Schwab. (1988) "Economic Competition Among Jurisdictions: Efficiency Enhancing or Distortion Inducing?” Journal of Public Economics, 35(3), 333-54.

Ostrom, Vincent and Elinor Ostrom. (1971) "Public Choice: A Different Approach to the Study of Public Administration.” Public Administration Review, 31(2), 203-216.

Ostrom, Vincent, Charles M. Tiebout, and Robert Warren. (1961) "The Organization of Government in Metropolitan Areas: A Theoretical Inquiry.” American Political Science Review, 55(4), 831-842.

Pace, R. Kelley and JP LeSage. (2009) Introduction to Spatial Econometrics. Chapman and Hall/CRC: Boca Raton, FL.

Pagano, Michael A. and Ann O’M Bowman. (1995) Cityscapes and Capital: The Politics of Urban Development. John Hopkins University Press: Baltimore, MD.

Peters, Alan and Peter Fisher. (2004) "The Failures of Economic Development Incentives.” Journal of the American Planning Association, 70(1), 27-37.

Peterson, Paul E. (1981) City Limits. University of Chicago Press: Chicago, IL.

Porter, M. E. (2000) “Location, Competition, and Economic Development: Local Agglomerations in a Global Economy.” Economic Development Quarterly, 14(1), 15.

Richards, Joseph W., Dan L. Starr, Adam A. Miller, Joshua S. Bloom, Nathaniel R. Butler, Henrik Brink, and Arien Crellin-Quick. (2012) "Construction of a Calibrated Probabilistic Classification Catalog: Application to 50k Variable Sources in the All-Sky Automated Survey.” Astrophysical Journal Supplement Series, 203(2), 32.

Rubin, Herbert J. (1988) "Shoot Anything That Flies; Claim Anything That Falls: Conversations With Economic Development Practitioners.” Economic Development Quarterly, 2(3), 236251.

Rubin, Irene S. and Herbert J. Rubin. (1987) "Economic Development Incentives: The Poor (Cities) Pay More.” Urban Affairs Review, 23(1), 37-62.

Schneider, Mark. (1989) “Intermunicipal Competition, Budget-Maximizing Bureaucrats, and the Level of Suburban Competition.” American Journal of Political Science, 33(3), 612-628.

Schneider, Mark and Paul Teske. (1992) "Toward a Theory of the Political Entrepreneur: Evidence from Local Government.” American Political Science Review, 86(3), 737-747.

Shleifer, Andrei. (1985) “A Theory of Yardstick Competition.” Rand Journal of Economics, 16(3), 319-327.

Spindler, Charles J. and John P. Forrester. (1993) "Economic Development Policy Explaining Policy Preferences Among Competing Models.” Urban Affairs Review, 29(1), 28-53.

Stekhoven, Daniel J. (2011) “Using the missForest Package." Swiss Federal Institute of Technology Zurich: Seminar for Statistics. http:/stat.ethz.ch/education/semesters/ss2013/ ams/paper/missForest_1.2.pdf

Stekhoven, Daniel J. and Peter Buhlmann. (2012) "MissForest--Non-Parametric Missing Value Imputation for Mixed-Type Data.” Bioinformatics (Oxford, U.K.), 28(1), 112-118. 
Stokan, Eric. (2013) “Testing Rubin’s Model 25 Years Later: A Multilevel Approach to Local Economic Development Incentive Adoption.” Economic Development Quarterly, 27(4), 301315.

Tax Foundation Staff. (2011) “A Sales Tax Word of Warning in Hawaii, New Mexico, South Dakota, and Wyoming.” Tax Foundation. Available at: http://taxfoundation.org/blog/salestax-word-warning-hawaii-new-mexico-south-dakota-and-wyoming, September.

Tiebout, Charles M. (1956) “A Pure Theory of Local Expenditures.” Journal of Political Economy, 64(5), 416-424.

Teske, Paul and Mark Schneider. (1994) "The Bureaucratic Entrepreneur: The Case of City Managers." Public Administration Review, 54(4), 331-340.

Teske, Paul, Mark Schneider, Michael Mintrom, and Samuel Best. (1993) “Establishing the Micro Foundations of a Macro Theory: Information, Movers, and the Competitive Local Market for Public Goods.” American Political Science Review, 87(3), 702-713.

U.S. Census Bureau. (2013) “State and Local Government Finance: Definitions.” United States Census Bureau. September 20 ${ }^{\text {th }}$, 2013. http://www.census.gov/govs/local/definitions.html\#u

Warner, Mildred E. and Lingwen Zheng. (2013) “Business Incentive Adoption in the Recession.” Economic Development Quarterly, 27(2), 90-101.

Zheng, L. and M. Warner. (2010) "Business Incentive Use Among US Local Governments: A Story of Accountability and Policy Learning.” Economic Development Quarterly, 24(4), 325.

(c) Southern Regional Science Association 2018. 